\title{
CUADROS Y POEMAS: UNA SINNTESIS DE REFLEXIÓN METODOLÓGICA SOBRE LA OBRA DE LUIS FEITO
}

\author{
Antonio García Berrio \\ Universidad Complutense. Madrid
}

0.1. Comparar y tratar de aproximar metodológica y estratégicamente el análisis de la pintura al de la literatura - o el de un cuadro al de un poemario- no es una ocupación excéntrica y ociosa. Existe ya una cierta tradición de ejercicios de análisis comparado entre las artes, que podríamos consiđerar «débil». Un tipo de actividades con principios y finalidades casi opuestos al espíritu de cientificidad que ha animado el desarrolto de las ciencias modernas, incluidas las humanísticas, como la filosofía, Ja lingüística, la poética y la teoría de la literatura y el arte. Como ideal lingǘstico y semiótico de cientificidad pensamos, por excelencia, en la evolución del pensamiento analítico y lingüístico que más ha afectado a nuestras disciplinas desde Wittgenstein, con modelos explícitos canónicos como el generativo-sentencial de N. Chomsky y sus seguidores, o el del macrotexto de J. S. Petöfi.

0.2. Para recordar ahora sólo algunas orientaciones más recientes en esa larga tradición, mencionaré la de la historiografía comparada entre las artes que se practicó especialmente en el primer tercio de nuestro siglo (P. van Tieghem, 1921), así como la mucho más reciente de la semiología del arte con base linguistica (O. Calabrese, 1980; 1985; J. A. Hernández Guerrero, 1990). La comparación historiográfica entre las artes correspondía al plan universalista de la "Geistesgeschichte", dentro de un ambicioso y bello programa general de Historia de la Cultura. La base idealista kantiana y hegeliana de ese proyecto historiográfico profundizó tal vez menos sistemáticamente la vertiente sicológica común implicada en el comparatismo, de lo que lo hizo el análisis inmanentista de los textos 
de los textos artísticos que empezó llamándose formalismo. Hay que advertir que a menudo es necesario recordar a los linguiistas e incluso a los críticos y teóricos de fa literatura, que el «formalismo" fue una corriente de crítica artística alemana y centroeuropea -Riegl, Wölflin, etc. - antes que una escuela rusa de crítica literaria: la escuela del «método formal» de Sklovskij, Tynjanov, Eikhenbaum, etc. A ésta, en todo caso, hay que considerarla una consecuencia rezagada dentro de la gran expansión formalista europea de la estética kantiana (I. Ambrogio, 1968; L. Doležel, 1991).

La historiografia comparada entre las artes, que deja sus huellas más o menos directas en las diversas tradiciones nacionales - de Weisbach a Hatzfeld y de Mario Praz a Ezio Raimondi; de Ortega y Gasset y Lafuente Ferrati a Valbuena Prat o a Camón Aznar-, así como en la constitución de corrientes y escuelas internacionales - de R. Pevsner a V. L. Tapiè, por ejemplo-, no se fijaba como objetivo directo profundizar en la clarificación de los textos por la vía de su comparación reciproca. Los poemas, las novelas, los cuadros, las esculturas o los edificios en sí mismos eran siempre objetos de significación teleológica, piezas en la argumentación diferida de hipótesis históricas distintas a ellas mismas. En último término, como en las filosofías de la cultura más dispares: la de $\mathrm{H}$. Taine o la de O. Spengler, las obras artísticas convocadas a la argumentación cultural eran "argumentos", evidencias intuidas y valoradas directamente $y$ en bloque para ilustrar alguna regla no inmediata de la lógica de la historia, política o intelectual. Las obras artisticas comparadas, piezas de convicción, eran aducidas por tanto como constataciones de experiencia convencional. De su inserción en el ejercicio de enjuiciamiento histórico salían raramente aclaraciones sobre sus principios estructurales constitutivos; y si alguna vez aquéllas llegaban a producirsé era siempre por vía indirecta y casi refleja e involuntaria.

0.3. La consecuencia inversa a la anterior para el conocimiento de las obras de arte concretas y de su «intertexto" cultural es, a mi juicio, la que ha representado el estudio semiológico en general, y en el caso concreto de nuestros intereses en este trabajo, la semiología de las artes plásticas (R. Passeron, 1962, 1980, pp. 33-48). Como es sabido, el análisis semiológico ha practicado un ideal de descripción estructural inmanente de obras de arte muy concretas (L. Marin, 1975, 1981; H. Damisch, 1972, 1984; J. L. Schefer, $1970,1971,1977,1980$ ), concentrando la mirada preponderadamente en el sesquema materials significativo del cuadro como texto (A. García-Berrio, 1989, pp. 327-333), de manera paralela a los alcances de la narratología estructuralista sobre la novela (J. Culler, 1979). Como fenómeno de moda intelectual, con actualidad plena, la vigencia metodológica de la semiologia de las artes plásticas ha sido sin embargo más bien breve y nunca absoluta (E. Battisti, 1974; H. Damisch, 1974). Ha tenido un desarrollo superior en países como Francia (L. Marin, 1970, 1978; M. S. Lagrange, 1973; R. Lindekens, 1976) e Italia (E. Garroni, 1973; P. Raffa, L. Nanni, 1980), al que ha alcanzado en el resto de Europa (C. A. Mattesen, 1974) y América. Ni siquiera en los lugares y momentos de máxima actualidad llegó a imponerse al nivel equivalente de la semiología titeraria, y todavía menos llegó a generalizarse sin reservas en la práctica habitual científica de los historiadores académicos y los críticos militantes de las artes plásticas $(\mathrm{O}$. Calabrese, ed., 1980). Sólo puntualmente, a favor de corrientes concretas de arte uestructuralista» como la abstracción geométrica y determinadas modalidades de arte modular, o bien de otras con una base constitutivamente lingüistica como el "conceptual", la metateoría semiológica ha conocido alguna divulgación fugaz, fuera del ámbito personal de especialistas como Louis Marín u Omar Calabrese (J. A. Hernández Guerrero, 1990, pp. 9-36).

Recientemente, el punto de partida del comparatismo entre las artes señala síntomas 


\section{CUADROS Y POEMAS}

de recuperación, como la fundación de publicaciones periódicas especializadas - «Words and Forms»- o la dedicación al tema de números monográficos en revistas generales de teoría de la literatura - «Poetics Today»-; así como también el asiduo cultivo de esta orientación por parte de especialistas tradicionalmente consagrados a otros campos de la investigación semiológica y retórica como Kibédy Varga, los componentes del Grupo $\langle\mu m,(1979)$, más recientemente Greimas y Geninasca etc. - . Todo ello testimonia por lo menos el mantenimiento de una legítima línea de estudio ya tradicional con sus mejores antecedentes en investigadores y grupos procedentes regularmente de la semiología literaria. A tal respecto, deben recordarse los escritos sobre pintura y attes figurativas de Mukarovský, los de Jurij Lotman (1979) y la Escuela de Tartù (B. A. Uspensky, 1969, 1976), o los de Umberto Eco sobre semiología del arte cinético, de la arquitectura y el urbanismo, entre las manifestaciones más conocidas. En esta situación de continuidad, resulta por tanto necesario y conveniente reflexionar y tratar de definir los objetivos peculiares y la intención diferencial con la que la orientación comparatista entre las artes puede enriquecer el conocimiento de la obra artística.

Refiriéndome ahora a mi propia experiencia, mis estudios sobre pintura participaban inicialmente de los mismos propósitos de conocimiento inmanentista y estructural de los textos literarios que caracterizaban los análisis descriptivos de la narratología, y en genera! los ejercicios críticos sobre los textos líricos, tal y como yo mismo los practicaba por entonces, hace diez o quince años. En el conjunto de ensayos y articulos que culminaron en mi libro Semiótica textual de un discurso plástico: E. Brinkmann (1979), se verifica la ventajosa perspectiva implicada en la consideración del cuadro como construcción textual de una modalidad de expresión. discursiva: la del lenguaje de la comunicación visual. Mediante el trámite elemental de proyectar a la plástica las categorías y estrategias metalingüisticas del análisis verbal artístico se producían observaciones muy interesantes en la exégesis crítica de la pintura, raramente entrevistas y aun más difícilmente conceptualizadas por la teoría y la crítica convencionales de las artes visuales.

1.1. Para empezar, resulta sorprendente y de efectos muy fructíferos considerar el texto plástico desde el reticulado de niveles y categorías habituales en el esquema lingüístico y semiótico (S. Kjourp, 1980). La difundida noción de la no neutralidad de los significantes artísticos, especialmenté los poéticos, de tan conocido arraigo tradicional retórico y formalista - «zaum» en los formalistas rusos, endorreferencialidad estética del enunciado poético en Jakobson y Lotman, etc. - aporta clarificaciones muy pertinentes al entendimiento de los móviles esencialistas de la abstracción y el informalismo más radicales del arte moderno. La condición "desautomatizadora» y el valor «transracional" de los elementos acústicos del poema, nociones ya triviales en la cultura crítica literaria, aclaran conceptos muy útiles para la literatura critica de las artes plásticas; sobre todo a aquella que se acoge a las paráfrasis críticas sobre la condición «inefable» del efecto poético de esos factores "prefigurativos" - estructuras del soporte, de la mancha, el empaste, las gamas de color, etc. - . Por su parte, las reglas y formulaciones más rigurosas de la sicología de la percepción visual encuentran en todos esos principios estilísticos y formalistas sobre la autonomía poética del significante el adecuado encuadramiento en una teoria estructurada de la experiencia artística (R. Arnheim, 1954).

En este primer nivel de to preconceptual y plástico, que se correspondía en términos muy amplios con el nivel fono-acústico de la poesía o con el de las unidades de la «segunda articulación» en el ya viejo esquema lingüistico de A. Martinet, radican importantes poderes de fascinación estética de la pintura, que eran ya familiares y sensibles a la 
misma concepción imitativa del arte, pintura y literatura, de Aristóteles. Conviene recordar un fragmento de la Poética escasamente destacado: cuando después de ponderar el placer intelectual de "reconocimiento», que fundamenta su concepción mimético-realista de todo arte - simbolizado por él además en este caso con el retrato de la pintura-, se advierte que, fuera del placer inherente al reconocimiento del retratado, una pintura puede deleitar también "por el diseño o por los colores" (1486, 15-19). Mediante esta fórmula de apariencias triviales, Aristóteles estaba ya creando indirectamente, al margen mismo de su teoría central de la figuración mimética, la previsión conceptual de los placeres más genuinos de la pintura, precisamente en los términos en que los ha exaltado radicalmente la independización informalista moderna de los componentes afigurativos (A. GarcíaBerrio, M. T. Hernández, 1989, pp. 127-128).

La concentración exclusiva en eł poder de delicia autónoma de elementos presignificativos como la luz y el color llega a fundamentar, según se sabe, la poética plástica del expresionismo cromático, elevando al más sensible de sus intérpretes, Marc Rothko, a una de las posiciones estéticas más elevadas en la realización de la plenitud pura del arte moderno. En España, la explotación temática de los elementos de este dominio presignificativo cromático tiene también representantes destacados en la poética luminosa de ciertas modulaciones de Eusebio Sempere, en el expresionismo cromático de Hernández Pijuán, y ocasionalmente en las series marinas, en plenitud absoluta de azul, de Jordi Teixidó. Pero al mismo tiempo, la responsabilidad decisiva en la instrumentación poética autónoma de estos constituyentes plásticos hace de ellos una condición básica en la estética individual de cualquier pintor con vocación moderna (C. E. Graham, ed,, 1965).

1.2. En el denso y rico panorama de la pintura española actual, con dimensión indiscutiblemente internacional, destaca objetivamente la exquisita y rigurosa pureza abstracta de Luis Feito, considerado ya uno de los maestros prestigiosos del arte moderno español. Formado inicialmente en Madrid, en la Facultad de Bellas Artes, fue miembro destacado, con Saura, Canogar, Rivera y otros, del grupo artístico El Paso, que a finales de los años cincuenta influyó decisivanente en la modernización artística española; asumiendo las corrientes plásticas de la modernidad internacional, europea y americana. En los cuadros delicadamente sensitivos de Feito se percibe, por excelencia, la rigurosa y depurada experimentación sensible de la que vengo hablando, sobre una combinatoria de significantes mínimos que es capaz de articular una rica pluralidad de textos variados y profundos, a la vez hondos y bellísimos. En el nivel presignificativo, los sucesivos momentos en la evolución de este interesante artista se esquematizan como tránsito de una primera etapa de abstracciones sobre tonalidades blancas a su período consolidadamente personal y definitivo de las composiciones aisladas y en dípticos, donde juega antes que la conquista de elementos nuevos, la progresiva renuncia de formantes cromáticos en opciones complementarias de amarillos, rojos y negros, con toques facultativos de ocres, marrones o azules (F. Huici, 1988).

Advertir el ponderadísimo efecto sensitivo de la gama cromática y del juego de formas del díptico de la figura 1, pone de relieve la dificultad de ejercicio en Feito de formas en equilibrada dialéctica. Se trata de verdaderos paisajes de la forma pura y del esplendor luminoso sin disonancias de la mancha, una tensa dialéctica de la exuberancia cromática, que sin embargo resulta siempre modulada y contenida por la disciplina sensible del pintor (M. Albert-Levin, 1968, p. 33). Del decisivo protagonismo de estos componentes absolutos presignificativos de la mancha y la combinación cromática de la obta en Feito da idea la constatación de cómo la lenta, matizadísima, evolución de su poética a través 


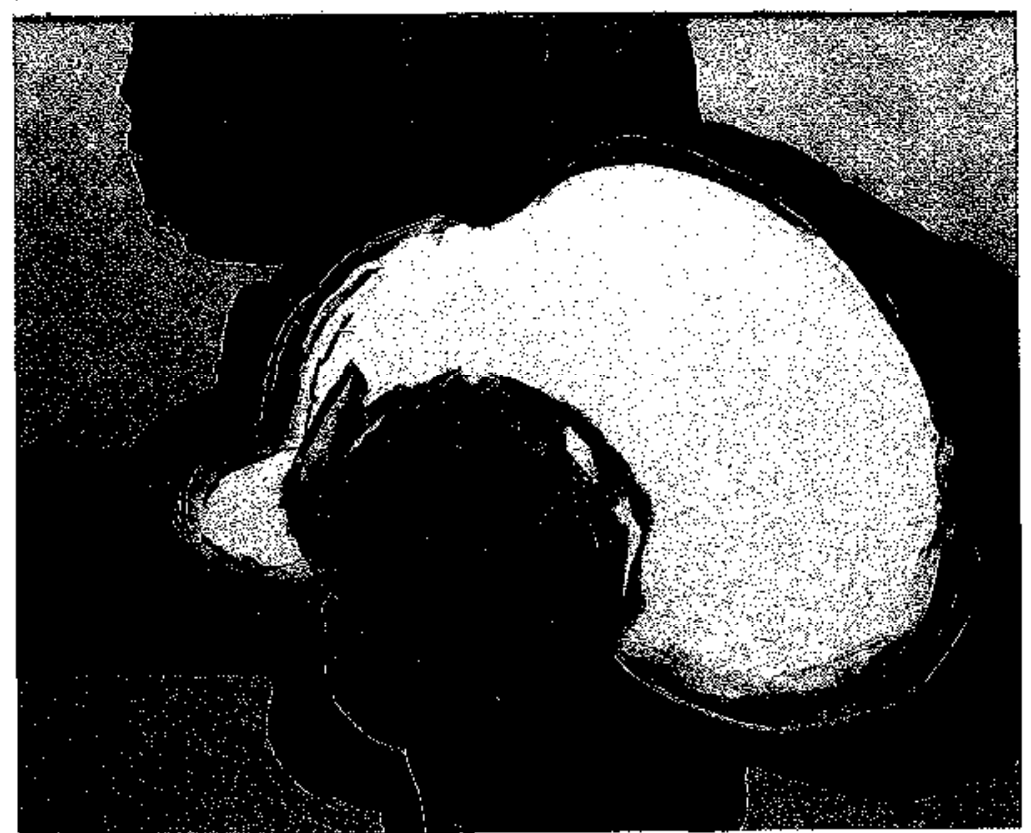

FIGURA 1

1966 PINTURA N.2538 $155 \times 100 \mathrm{~cm}$. COLECCION PARTICUL.AR. NUEVA YORK 



\section{CUADROS Y POEMAS}

de centenares de composiciones, nunca idénticas y siempre atractivas, ha encontrado sus momentos de inflexión y de variación más decisivos en marcas y características de los materiales del cuadro que, a su vez, traducen e interpretan motivos y emociones profundas de su necesidad sicológica de expresión. El fenómeno más perceptible y decisivo de este nivel fue en principio la sustitución del óleo por el acrilico, todo un síntoma simultáneo de su transferencia de París a América; coincidiendo con la crisis de la pintura moderna europea y la conquista del "pop» americano. En esta misma línea profundamente sintomática de protagonismo de los materiales textuales presignificativos, se señala recientemente en Feito una nueva y decisiva modificación de su gama cromática a favor de la dulce exquisitez de grises suaves, rosados y pastel, asi como la incorporación de pigmentaciones anómalas de revolucionario y logrado efecto estético como la purpurina de oro. Un conjunto de decisiones que traducen los contrapuestos sentimientos de la conciencia europea de estética decorativa, muy activa en la delicada sensibilidad de Feito, en términos de asimilación y respuesta polémica a la provocación, a la ruptura estética del arte americano, nuevo y agresivo.

1.3. Téngase en cuenta que, siendo Feito sin duda un pintor de extraordinaria cultura y capacidad, en la antítesis por tanto de una fogosa espontaneidad intuitiva, su rigurosa experimentación técnica durante más de cuarenta años de producción se ha concentrado básicamente en una minuciosa evolución de los componentes mínimos de base de la pintura ( $\boldsymbol{P}$. Restany, 1968, p. 26). Una situación que resulta representativa sobre todo en las etapas más poblemáticas y silenciosas de su investígación, como en el período de más de doce años, entre 1970 y 1982, al que corresponde la Pintura de la figura 2. En este largo espacio de tiempo, Feito ensayó con meticulosa delicia, junto a modificaciones casi imperceptibles pero definitivas de la forma, el dominio luminoso de la composición, modulando la gradación de efectos de un color $\rightarrow$ rojo, crema o amarillo- en soledad absoluta elemental.

Soy consciente de que la asimilación de los elementos básicos de la pintura — soporte, empaste, pigmentos, manchas, formantes primarios del diseño como los grafismos presignificativos, etc. - a los constituyentes fono-acústicos del enunciado poético implica no pocas necesidades de aclaración y de reajuste. Es una de las tareas que demanda aún en el futuro más análisis y discusiones de detalle dentro de la propuesta metodológica que practico, para una comparación lingǘsticamente exacta y no puramente metafórica entre el poema y el cuadro, siguiendo el esquema semiológico de niveles (A. García-Berrio, $M$. T. Hernánđez, 1988, pp. 42-49). Como veremos en to sucesivo, la aproximación entre pintura y poesía de unidades y niveles morfológicos, gramaticales, semánticos y pragmáticos en la doble perspectiva micro- y macrotextual resulta más factible y evidente, que estas otras en el nivel presignificativo de la "segunda articulación". Sin embargo no cabe duda de que, partiendo de los conceptos formalistas del componente transmental del sonido poético y, más en general, de la capacidad de autorreferencialidad estética que caracteriza a los significantes artísticos, se refuerzan las evidencias de necesidad solidaria sobre el valor y la virtualidad paralela de las entidades proto-significativas de la obra artística literaria y visual.

1.4. En el ejemplo del pintor cuya obra tomo como objeto en todo este trabajo, Luis Feito, la profunda fascinación estética de sus pinturas debe una base importantísima, si no fundamental, a la ponderada consideración de las valencias más puramente emocionales, más plásticamente sentimentales, presignificativas y prerreferenciales de sus exquisitos 


\section{ANTONIO GARCÍA BERRIO}

materiales significantes. El mosaico cromático y luminoso que constituye sus pinturas y la ordenación preconsciente - presintáctica o protosintáctica según se prefiera--, puro impulso de orientación antropológica, de la estructura de manchas y de formas "construye» el texto del cuadro como espacio esencial de impacto emocionante (P. Restany, 1968, pp. 26-28). Poseyendo Feito una capacidad intelectual y analítica de reflexión y de análisis consciente que bien pueden hacerle figurar entre los artistas más intelectuales de la modernidad española y europea, destaca en él sin embargo como una de las características más logradas de su personalidad y de su obra, la búsqueda de la belleza absoluta para la recuperación casi adivinatoria y mística de los valores de fascinación espontánea: colores, luces y formas en estado de pureza nocturna, previos al inevitable ejercicio de análtsis y de reflexión consciente de la construcción - o "reconstrucción»- artística del cuadro como espacio reordenado (F. Alport, 1955).

2.1. La consideración de unidades y componentes del nivel gramatical en el esquema semiótico ha ofrecido tradicionalmente, como se sabe, numerosas e importantes pautas para el comentario estilístico de la literatura. Morfológicamente la observación de la fisonomía textual de piezas concretas configura importantes sensaciones y emociones codificadas y transmitidas por los textos. Así por ejemplo la presencia o ausencia del predeterminante articulo o la diferencia entre el uso de formas determinadas o indeterminadas, en las lenguas que construyen todas esas variables, introducen en el texto sugerencias más esenciales - por ausencia - o más existenciales - por presencia - antes aún que la de determinación o indeterminación y universalidad (A. Alonso, 1961, pp. 125-160). Y otro tanto puede decirse respecto del artículo sobre su comportamiento anafórico y catafórico textual. Tan ilustrativas como las consideraciones estilísticas señaladas sobre el artículo son las que se deducen del estudjo artístico de la adjetivación literaria y fundamentalmente poética: específica y explicativa, antepuesta y postpuesta, etc. En este aspecto el estudio de la intencionalidad estilística del epíteto y su tipología de uso constituye una de las reflexiones obligadas de la estilística y la poética linguística de cada lengua nacional (G. Sobejano, 1970; para el caso del español). La densidad conceptual de los textos con abundancia de formas nominales frente a la sensación de dinamicidad y flujo de aquellos en los que predominan las formas verbales, es otro fenómeno fundamental en la plasmación de la intencionalidad estilística de la expresión, presente ya desde las consideraciones fundacionales platónicas sobre las «clases de palabras». Y análogas deducciones pueden establecerse sobre las posibilidades artisticas o puramente expresivas de constitución del texto a propósito de la observación del componente pronominal (R. Harweg, 1968), etc.

Globalmente hablando, la estructura morfológica y aún más la actividađ sintáctica de las piezas textuales, constituyendo en su conjunto la gramática de un fragmento de discurso verbal dado, determina y define el espectro estructural de cada texto. Por eso mismo todo ese entramado gramatical de unidades y constituyentes de solidaridad afirma y descubre la intención artística global, así como los niveles y formas emocionales e imaginativas en los que aquélla se despliega. El resultado de todo ello, en los textos artísticos, se traduce en sensaciones y sentimientos vinculados al conjunto de impresiones causadas por los elementos morfológicos, los «monemas" constituyentes (R. Arnheim, 1980). Entre estos predominan, además de las impresiones estrictamente vinculadas al «registro» inmanente de formas, las sensaciones de dinamización textual de las piezas componentes (T. Gella, 1978), la cual es mucho más activa e interdependiente en los textos artísticos que en los simplemente estándar y referenciales, debido a un sentimiento de «solidaridad necesaria» superior, de cohesión interdependiente entre las piezas, en que 


\section{CUADROS Y POEMAS}

se plasma el intenso laboreo de la intencionalidad expresiva poética (A. García-Berrio, 1989, pp. 62-63).

2.2. Todo lo que acabo de decir respecto a rasgos estilísticos bien conocidos y consensuados por la crítica de los textos literarios, puede trasladarse con muy escasas variaciones al terreno de la pintura (H. L. Joffé, 1966; C. L. Curter, 1976). El pintor elegido como ejemplo en este artículo, Luis Feito, y los contados cuadros del mismo que se reproducen aquí, permiten ilustrar suficientemente la decisiva influencia que, sobre el efecto general estético de sus obras, tienen las manipulaciones intencionales de los componentes que podemos llamar con toda propiedad gramaticales: morfológicos y sintácticos. Quiero advertir, sin embargo, que mi elección de Feito en este caso no obedece a razones de oportunidad o de idoneidad especiales, que lo hagan particularmente apto para este tipo de análisis semiológicos y de especulación metateórica. La diversidad de estilos de los pintores estudiados por mí mismo en trabajos anteriores bajo este mismo esquema analítico semiótico - Velázquez, Zurbarán o el Greco entre los clásicos; Picasso, Gris, Miró, Brinkmann, Torner o Saura entre los modernos-- prueba la condición lf́cita de su generalidad metodológica con muy escasas excepciones al ámbito global de las artes visuales (A. García-Berrio, 1979; 1991; y en colaboración con M. T. Hernández, 1987; 1988).

Para empezar, lo que caracteriza a Luis Feito es el sobrio esfuerzo creativo de tensión económica controlando la concentración de los constituyentes morfológicos de su sistema. Una tendencia personal muy genuina desde que en sus obras de los años sesenta se constituye ya el bello y reconocible "paisaje» abstracto personal, concretado en rotundas formas de color fuertemente compactas y con perfilados límites, después de las inciertas nebulosas magmáticas de los fondos de su primera etapa de grafismo esquemático y de las del periodo inicial de transición difusamente digestivo y nocturno. El elemento morfológico imprescindible en todas estas composiciones de la primera plenitud de Feito, pinturas y dípticos, es la forma redondeada, solar, iniciada hacia 1960. La marcada presencia de ese «morfema" centra, gobiema y regula sintácticamente la "disposición» de cada cuadro como texto. De tal manera que lo fundamental del reputado arte de Feito en aquellos años de plenitud creativa puede definirse fácilmente como la economía sensible de una sintaxis de relaciones formales y cromáticas, que regulan bajo una retórica personal muy estricta la combinatoria siempre original e inagotable de un inventario morfológico escueto, altamente personal y con efectos de belleza subyugante. Unos resultados estéticos que ponen a prueba con éxito la sobriedad cuantitativa del controlado sistema gramatical del pintor (A. Garcia-Berrio, M. T. Hernández, 1988, pp. 84-89).

La mesurada economía retórica que estoy ponderando en Luis Feito como clave del comportamiento expresivo de su estilo, no es por sí misma un valor de resultado poético absoluto. La fecundidad gramatical de muchos pintores es igualmente concretable bajo la tendencia opuesta: es decir, la proliferación imaginativa de morfemas, de elementos iconográficos logrados en formas de sólido acento personal, así como en la flexible articulación de las estructuras sintácticas de disposición textual. Dentro de la pintura abstracta española, importantes artistas como Mompó, Farreras o Lucio Muñoz pueden ser caracterizados, y de hecho se les valora fundamentalmente, por la variable fecundidad original de sus formas, morfosintácticas en el primero y materiales presignificativas en los otros dos. Sin embargo, bajo esta perspectiva destaca el caso del pintor Luis Gordillo, sin duda uno de los más brillantes e interesantes protagonistas españoles del arte contemporáneo con proyección internacional ( $F$. Calvo Serraller, 1986), fundado sobre todo en su riquísimo catálogo de invención morfológica en el que se concreta el dinámico flujo 


\section{ANTONIO GARCIAA BERRIO}

imaginario de una capacidad de simbolización subconsciente verdaderamente única (A. García-Berrio, M. T. Hernández, 1988, pp. 45-46).

Lo que opone la personalidad sicológica y artística de Luis Feito a la de todos estos pintores con desbordada exuberancia morfológica no afronta una contraposición puntual de valor sino un principio histórico de gusto, creativo y receptor, que ha caracterizado no sólo las diferencias individuales y personales entre artistas sino incluso el perfil completo de edades (P. Restany, 1968, p. 26). La estética y el tipo sicológico de la reconcentración intensa del sentimiento hermanan a Feito, a través del tiempo y del espacio, con la depuración esencial del Giotto, la pureza lineal de las formas renacentistas de Botticelli, la esencia esquemática de Mondrian y de Klee, o el sentimiento de equilibrio de densidad que campea en las construcciones luminosas de Rothko y en los lienzos abiertos de Lucio Fontana. En el latido contrario, la emoción abigarrada y barroca del Bosco, del Greco y de los venecianos, de Pollock, de Motherwell o del joven mallorquín Miguel Barceló. Gramática y estilo preciosista de la economía esencial, viejos en la historia del despliegue del espíritu artístico occidental en corrientes de estilo como el aticismo o el tacitismo; frente a las delicias laberínticas de la expresividad asianista o rococó, del grupo de Laoconte o de las diversas escenas de la Historia de María de Medicis de Rubens en el Louvre.

2.3. Naturalmente el efecto poético común posible en las manifestaciones de las dos tendencias contrapuestas de la revolución gramatical artistica, se vincula a una acertada articulación textual de la expresividad - diferente también, como es lógico, en cada uno de los estilos-, que es capaz de expresar y de inducir, en la doble perspectiva del emisor y del receptor, efectos imaginarios y fantásticos de poderosa conmoción. En el caso de las poéticas de sobria economicidad, como la de Luis Feito, el sentimiento de lograda hermosura se vehicula en este nivel a través del austero ejercicio de una retórica de gestos plásticos mínimos, ensayados y calculados en el espesor de su profundidad espiritual mediante el tanteo escrupuloso de variantes más intensas que extensas en la constitución morfológica de formas y de manchas de color. Así, desde la sintaxis textual del cuadro se crea el límite directivo absoluto de las decisiones morfológicas y sintácticas concretas, icónicas y dispositivas. En consecuencia, se valoran sobre todo en la pintura en dípticos los efectos de contraste luminoso de las amplias superficies plenas de uniformidad cromática, templadas habitualmente en la gama de amarillos contrapesados por el espacio de anecdotario formal donde se articula la permanente variación sintáctica de los constituyentes morfológicos (G. Boudaille, 1968, p. 20).

2.4. En términos rigurosamente lingüísticos se puede contemplar y explicar quizás con más claridad la línea de evolución de un artista como Feito. Y siendo la suya, como ya se ha visto, una poética de extraordinaria sobriedad gramatical, las sucesivas transformaciones de su morfosintaxis icónica ilustran las hondas exigencias íntimas que justifican la evolución. Así, el primer perfodo de plenitud abstracta, europeo y parisino, de las pinturas y los dípticos en los an̂os sesenta, al que acabo de caracterizar en términos de formas de expansión redondeadas a partir del círculo solar característico, señala su crisis en las escasas obras del decenio de transición siguiente precisamente a través del cuestionamiento radical de sus formantes morfológicos y de sus movimientos sintácticos esenciales y más característicos. Los años de transición, que no fue solamente plástica sino también cultural, espacial y espiritual, marcada por el cambio de residencia de París a Canadá y definitivamente a Nueva York, se ven representados en el plano de lo protosignificativo por el 
cuestionamiento más externo del material: sustitución del óleo y de una cierta densidad de los materiales de carga por el acrílico y el tratamiento más delicadamente plano dé las superficies del lienzo. Pero en correspondencia con esa primera decisión, confesadamente trascendental para Feito, la difícil etapa del cambio deja trazas decisivas en su tortuosa diferenciación interior de la morfología y la sintaxis (F. Huici, 1988; A. García-Berrio, M. T. Hernández, 1988, pp. 86-87).

El paso del círculo al ángulo, del disco solar al triángulo trascendental, de la construcción en desplazamientos gestuales de trazo curvo a la disposición rectilínea del reticulado espacial básico, marcan las diferencias entre los dos grandes momentos de plenitud estilistica de Feito, que se corresponden aproximadamente con su producción en los decenios sesenta y ochenta. En los ensayos del período intermedio que han superado la exigente revisión del pintor, se aprecia primero, entre 1970 y 1974, la disminución cuantitativa de los morfemas solares de contraste, en paralelismo con el oscurecimiento en verdes y más raramente en grises y ocres oscuros de los fondos. Después, entre 1975 y 1980 , el resurgir en los rojos y amariflos tradicionales del fondo - ahora sin embargo diferenciados de las primeras épocas por la matización del acrílico- establece su correspondencia con la lenta transformación del circulo emblemático de Feito en la retórica del morfema triangular y las formas lineales que lo desarrollan a partir de 1975 .

Lo que en último término destaca siempre en la evolución de la obra de este pintor, es la condición de economía sistemática que regula la progresividad sintáctica de las distintas etapas de su producción. Mediante ella, queda constituido el texto de cada cuadro dentro de una retórica rigurosa y austera de componentes morfológicos esenciales en inventarios tópico-icónicos cerrados, que se combinan con el acierto de una lograda eficacia estética y semántica. Pero todo ello, al mismo tiempo, bajo el instinto de moderación y de mesura que define la personalidad artística de Feito en todos los niveles de la articulación expresiva y comunicativa.

3.1. Dentro de un discurso comparativo como el que se practica en este artículo, no hay que esforzarse en ponđerar la raíz fundamental semántica y pragmática en que se funda diferencialmente la renovación plástica del arte moderno. En este aspecto, incluso, las artes visuales lideradas por la pintura manifiestan su capacidad de ilustrar el comportamiento de la literatura. La tendencia general antimimética del arte, que se inició a partir de la revolución romántica y que se consolida en las vanguardias artisticas, implica un ideal de profundización antirrealista, el cual supone en último término un proceso de estilización abstracta y aformal (J. M. Floch, 1981, pp. 135-158). Queda claro que, por grandes que puedan haber sido los avances en ese proceso en la novela moderna de Sterne a Joyce y en la poesia desde Baudelaire a Breton, o desde Blake a Wallace Stevens, los resultados de la «abstracción» literaria no pueden ser tan radicales y constatables como los del informalismo del arte visual. El lenguaje natural con el que opera obligadamente la literatura, puede desarraigar difícilmente su material significante, las palabras, de la voluntad y el hábito significativos que están implícitos en el uso comunicativo estándar del lenguaje. Tales hábitos son irređuctibles, incluso en los casos del simple flujo vocal con el que han experimentado las tendencias más vanguardistas del futurismo, del surrealismo, el letrismo y la poesía visual. Para la pintura abstracta, por el contrario, la desafección icónica de la mancha respecto a la convención significativa histórica ha sido tarea casi natural, sin necesidad de esfuerzo (F. Calvo Serraller, 1987).

Semánticamente por tanto la abstracción moderna ha supuesto antes una liberación 


\section{ANTONIO GARCIA BERRIO}

estructural, que un ejercicio laborioso de omisión de los indicios significativos que lastran históricamente la expresión literaria y la palabra poética (\$. K. Langer, 1953, 1957; E. H. Gombrich, 1959). Es en esa condición misma, de aparente facilidad en último término, donde se han gestado habitualmente los prejuicios y sospechas más rudimentarios contra la supuesta fragilidad estética del arte moderno, especialmente en las poéticas como la de Luis Feito con vocación más rigurosamente afigurativa. Sin embargo este tipo de argumento manifiesta una radical debilidad sensitiva y, como he dicho antes, una tosquedad conceptual rudimentaria. Es evidente que en la liberación aformalista de la semántica de la abstracción moderna pueden refugiarse $-\mathrm{y}$ de hecho asi ha sucedido, a favor sobre todo de conocidas perturbaciones extraartísticas: comerciales, sociales y otras, a las que no creo necesario referirme aquí —casos de simulación y falsificación axiológica con una impunidad elemental, la cual está vedada a las formas tradicionales de la semántica plástica medidas en términos de iconografía naturalista; al menos así puede considerarse para la recepción menos sensible y experimentada.

3.2. Pero los conocedores profundos del arte moderno, quienes son capaces de seguir en la rigurosa estética de Feito, por ejemplo, los hallazgos sustanciales de un análisis gozoso de la realidad y de los abismos del autoconocimiento expresados en su sistema luminoso de formas bellísimas, no son gentes engañadas con los trucos de un arte de recursos y facilidades impotentes. Por el contrario, el gustador informal de la abstracción distingue, más allá de las apariencias vulgares, los logros expresivos de las frustraciones; porque tal espectador iniciado reconoce en la arreferencialidad más inmediata de la informa de Feito un expediente de adensamiento esencial en los poderes de experiencia luminosa de la pintura. Liberando la luz, el color de la pintura y en general la plural capacidad de expresión sensible de los significantes plásticos respecto de sus vinculaciones más materiales con las equivalencias naturalistas de la tealidad inmediata, el salto atrevido de la abstracción moderna emplazó la pintura en la culminación de sus poderes de representación del paisaje exterior tradicional, estilizándolo, y al tiempo enriqueciéndose con la multiplicidad de escenarios intimos del espíritu, inasequibles o por lo menos ensombrecidos y mediados por las servidumbres iconográficas de la figuración clásica.

3.3. En términos semánticos, la positividad del proceso de liberación figurativa referencial que ha aportado el arte abstracto, se explica óptimamente en el ámbito de la polisemia (E. Garroni, 1964). La figuración naturalista del arte mimético tradicional encasillaba las valencias autónomas de la expresividad plástica visual en el estrecho cauce significativo de las reglas iconográficas de representación realista, presididas por un ideal fuertemente monosemizador del mensaje. Naturalmente que las condiciones de verosimilitud y de "parecido" no lo eran todo en el arte tradicional, como reconocía ya el propio Aristóteles y los genios de la mímesis renacida desde Leonardo a Alberti (G. Mathieu, 1959, p. 322); pero a decir verdad, la mayoría las interpretaba conscientemente como si así fuera. Actualmente los artistas abstractos más aventajados, como Feito, reconocen en Giotto y en algunos pintores primitivos de la escuela senesa un instante de dificil equilibrio en la evolución del arte europeo, donde el predominio de la inflexión figurativa y naturalista resultante osciló en momentos estéticos de indiferenciación espiritual y técnica, que hubieran podido tal vez inclinar la evolución posterior de la pintura hacia las expresiones más puras y libres del color y de la luz, en un auténtico desleimiento polisémico de las formas (E. H. Gombrich, 1966).

Esta fe histórica en la plurivalencia semántica de la pintura, sea valida o exagerada, 


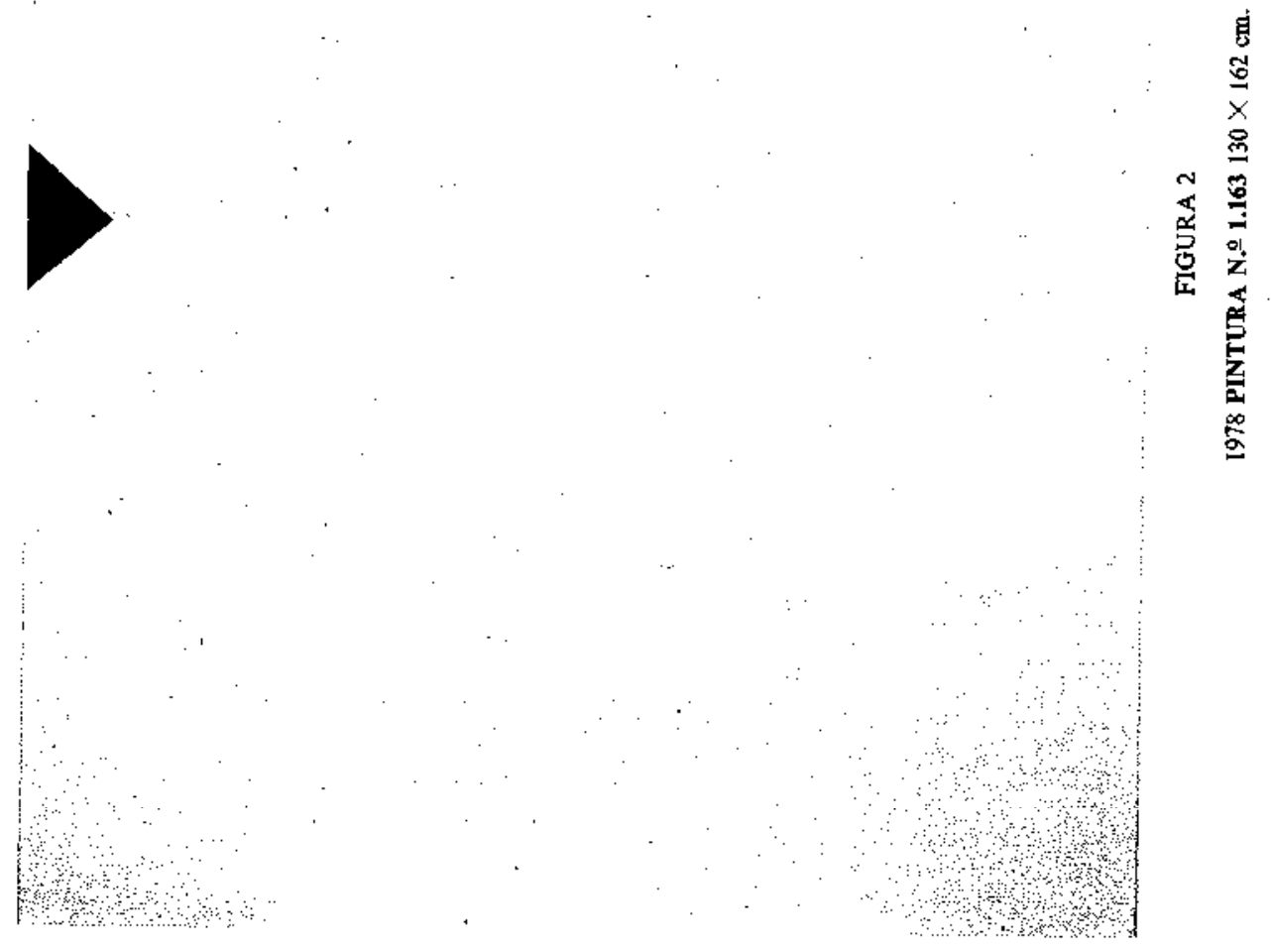





\section{CUADROS Y POEMAS}

alimenta ciertamente la voluntad estética de artistas como Luis Feito. La libertad icónica de la plástica abstracta no resulta así para sus más dignos representantes una licencia semántica eximente, como lo contrario no vincula a una necesidad referencial a los más vigorosos expresionismos figurativos actuales -sea el caso de Georg Baselitz (R. Fuchs, 1980 , p. 20)-. Antes bien se trata de una aspiración para los artistas actuales más dignos, cualquiera que sea su tendencia, a logros estéticos absolutos en una escala distinta de la de facilidad o dificultad. Es la polivalencia significativa del mensaje visual, que cotiza a muy altas cotas de riesgo y de depuración creativa. Para tranquilidad de los menos iniciados, apunto el dato disuasivo de la brillante y rigurosa formación técnica de Feito, adquirida en largos años de aprendizaje tradicional figurativo de la academia clásica en el centro de estudios más prestigioso de España durante la juventud del artista: la antigua Escuela de Bellas Artes de San Fernando de Madrid, actual Facultad de Bellas Artes de la Universidad Complutense. A otro objeto, pero en el mismo sentido, comparece el hecho constatable de la condición sólo secundaria y relativamente abstracta de la pintura de Feito, la mayoría de cuyas obras de la época de plenitud solar se dejan interpretar correctamente y sin excesos como verdaderos paisajes esenciales. Referencias posturales delicadamente estilizadas en la realidad de la plenitud diurna o de la crisis nocturna, según los casos y los estados de ánimo, y acrísoladas a través del noble filtro de la sensibilidad y de la percepción sentimental intimas del artista (G. Gassiot-Talabot, 1968, p. 78). De tal manera que el proceso de trascendentalización mística de los datos y apariencias sensibles del mundo, que sus críticos han señalado habitualmente como la instancia creadora más representativa en el arte de Feito, contribuye a explicar por sí mismo este itinerario de transfiguración semántica, transubstanciación, si vàle el simil habitual demasiado rimbombante, del emplazamiento casual de los referentes monosémicos en símbolos de necesidad esencial depuradamente polisémicos.

En la rica casuística de grados y tendencias que conoce y que requiere para su necesaria clarificación el fenómeno plástico de la abstracción moderna (W. Grohmann, 1966; E. Crispolti, 1968), la opción abstracta cultivada por Feito —con la rigurosa permanencia de las certidumbres estéticas esenciajes de un Rothko, un Klee o un Mondriandebe ser emplazada, a mi juicio, en el nivel de mesura y equilibrio semántico que caracteriza en general todas las disposiciones creativas de Feito. Remitiéndome aqui a la tipología semántico-pragmática de la abstracción establecida en la Poética del arte visual (A. GarciaBerrio - M. T. Hernández, 1988, pp. 83-98), la interpretación estilizada de los referentes naturales que practican Feito, Lucio Muñoz o Eusebio Sempere entre los artistas españoles de su generación, se sitúa en un punto medio entre la producción icónica de referentes exentos como la cultivada por Tapies en los mejores momentos «muralistas" de su obra, y la anulación total de la instancia referencial externa que caracterizaba más directamente, en el otro extremo, el arte sublime de Manuel Mílares y sobre todo actualmente la voluntad deconstructiva de ruptura radical con toda estructura semántico-simbólica, a la que se extienden casos evolucionados de abstracción polémica como el de Broto ( $F$. Calvo Serralier, 1988).

Luis Feito, temperamento absorto en el tormento casi místico de la vivencia creativa (F. Mathei, 1968, p. 40), no conoce apenas -o por lo menos no se le reconocen en las marcas explícitas de su obra- las convulsas raíces sociales y culturales de zozobra que alimentan la actitud intelectual del escepticismo deconstructivo. Entre los fundamentos más rigurosos que pueden invocar actualmente los proyectos utópicos de abstracción sentántica más radical, debe contarse el contagio espiritual de la filosofia de la deconstrucción. La ideología artística de Feito se aloja más bien en los antípodas de cualesquiera 


\section{ANTONIO GARCIA BERRIO}

formas de agnosticismo escéptico. La vocación artística de Feito se funda en una semántica de transcripciones intimas alimentadas por una búsqueda radical de la Belleza esencial; la simbolización plástica de Feito arranca de vivencias atormentadas y vacilantes como formas de aproximación a las hipótesis significativas de un adeseo», que no ha conocido quiebras definitivas de renuncia ( $P$. Restany, 1968, pp. 26-28).

La convergencia de actitudes de depurado equilibrio que vamos teniendo ocasión de señalar en los diferentes niveles y coyunturas del discurso artístico de Feito, apuntan hacia la axiología tradicional del clasicismo. El desarrollo actual del arte y de la sociología moderna del gusto permiten considerar hoy, sin sombra de paradoja, que la obra abstracta de Feito hace de él un verdadero clásico en la modernidad; a lo que se debe añadir desde el punto de vista del juicio de valor, que este riguroso, delicado y profundo attista es uno de los más representativos clásicos de la modernidad española e internacional ( $\mathrm{F}$. Huici, 1988). Clasicidad como equilibrio, que instrumenta lo abstracto en depuración simbólica sin abdicación referencial deconstructiva, y que cultiva la polisemia aformalista como vehículo idóneo de ensanchamiento y de profundización de una elaborada propuesta de mensaje autorial, la cual sabe ser respetuosa además con la libertad receptora de los contempladores en términos de polivalencia abierta; pero que se mantiene en todo momento firme y fiel a la "tendencia» de su deseo. Arte moderno por tanto en el alojamiento problemático de su poética: en dialéctica con el absoluto escéptico de la deconstrucción y con los relativismos semánticos de la estética de la recepción y de la obra abierta; pero también arte de soluciones clásicas, las de Feito, en la fidelidad más auténtica a los principios tradicionales de la significación como destino đel arte.

4.1. En relación con los acalorados debates actuales en la teoría literaria sobre la naturaleza del significado artístico y el papel del autor y de los receptores en la construcción del mismo (A. Garcia-Berrio, 1989), la experiencia creativa de un pintor como Feito puede resultar altamente ilustradora. Por lo pronto, las hipótesis deconstructivas se excluyen por sí mismas: la pintura es un lenguaje al que no se le puede aplicar el principio fundador de la «diferencia». A menos que se quiera argumentar también que la pintura, como el lenguaje, se funda en las oposiciones binarias - blanco, negro; cálido, frío, etc., referidas por ejemplo a valores y gamas cromáticas-desnaturalizantes, según Derrida, de las categorias absolutas por efecto de alguna tradición metafísica deturpada. Pero esto, como es lógico, no tiene pertinencia dentro del sistema complejo perceptivo en que se funda la peculiar semántica visual de la pintura (R. Arnheim, 1954). Por el contrario, aludir a la pintura como lenguaje artístico - de la misma manera que Derrida apela a una "escritura» en pureza, que él no identifica pero que es fácilmente identificable con el ideal habitual de escritura poética, tal y como lo asimilaba un autor tan próximo a Derrida como el propio Maurice Blanchot-implica señalarla como alternativa estética a los límites del conocimiento racional, filosófico y científico: un alegato de moda actualmente bajo el aliento remoto de Nietzsche y el más próximo de Heidegger o de Rorty (F. Lyotard, 1984; G. Vattimo y otros (eds.), 1983), al que auguro una vigencia escasamente prolongada. Pensamiento deconstructivo y creación pictórica no cuentan por tanto, a mi juicio, con zonas de convergencia interesantes.

Respecto a las razones de relativismo pragmático características de la estética de la recepción o en general de las poéticas de la lectura, la simple experiencia artística de la ulucha del autor con el cuadro» que describe la mayoría de los artistas, como el propio Feito (F. A. Viallet, 1968, p. 62), en términos incluso agónicos, ofrece base suficiente para emplazar la cuestión con realismo en su alojamiento razonable. Resulta evidente 


\section{CUADROS Y POEMAS}

que todo mensaje plasmado en el soporte de la obra lo ha depositado la capacidad consciente e inconsciente del creador; y a este respecto conviene recordar aquí que a menudo se descuentan o desacreditan en la práctica, dentro de las apologías sobre la responsabilidad receptora de las «lecturas artísticas", los efectos textuales de la actividad no inmediatamente explícita y consciente de los autores, como si se tratara de productos indiferentes ajenos a la excepcionalidad del talento individual creativo de los mismos. $O$ incluso más exageradamente, se desplazan todas esas valencias involuntarias de las obras a una especie de reserva universalista previa, que se suele atribuir con ligereza al patrimonio exclusivo de la construccion receptora del sentido. Sin embargo parece evidente que, a partir del soporte virginal del cuadro, toda marca y traza emplazada por la iniciativa gestual del pintor es actividad - acierto o desacierto conceptual y estético- exclusivamente imputable a las decisiones conscientes o inconscientes de su personalidad creadora -excepcional o artísticamente adocenada-. Esta afirmación, que puede resultar ociosa o incluso atrabiliaria en el discurso habitual de la teoría de las artes visuales, ha liegado a representar un principio de pronunciamiento problemático y nada obvio en el dominio de la teoría de la literatura; a tal extremo alcanza el confusionismo producido a partir de la radicalización de ciertos análisis paradójicos de la deconstrucción y de las estéticas đe la respuesta lectora (J. Ellis, 1974; P. De Man, 1981; J. Culler, 1982).

No se trata de negar lo evidente: el receptor tiene un papel imprescindible en la constitución del sentido que es el término de todo proceso significativo. Dada la naturaleza en superior medida autorreferencial e intertextual histórica de las obras artisticas, la polisemia resultante de las mismas acrecienta el valor de las iniciativas descodificadoras de los receptores. El arte ensancha el ámbito monosénico de los mensajes conceptualdenotativos bajo la polisemia estético-connotativa. Pero a partir de esas premisas innegables, el entusiasmo crítico ante el papel recientemente exaltado de la recepción produce frecuentes exageraciones (W. Iser, 1976; R. C. Holub, 1984). Sin embargo, la responsabilidad secundaria del receptor-intérprete - al menos incuestionablemente tal en la dimensión temporal y causal - no debe ser exaltada a costa de la condición primera - cuando menos, indiscutiblemente en la dimensión genética antes aludida- de la iniciativa autoriał. Es el autor quien produce consciente o subconscientemente la previsión textual legítima de las varias iniciativas de lectura inscritas en el cuadro o el poema (J. S. Petöfi, 1975; U. Eco, 1979). Se entiende, claro está, de las respuestas e interpretaciones sensatas y necesariamente atribuibles a mediación de la obra concreta; y no, lógicamente, las que se independicen totalmente de su referencia objetiva, o las que la asuman marginalmente como mero pretexto (U. Eco, 1990).

Volviendo a la experiencia que brinda la reflexión concreta sobre la actividad creadora de Luis Feito, es conocida la tensa ascesis espiritual en la que se producen los momentos -etapas, rachas- de productividad artística de este creador sublime. Su tenso acecho permanente de la situación espiritual que crea «el estado de gracia» sicológico del que surge la intuición renovadora, el desłumbramiento inicial sólo entrevisto. Después, las etapas de larga soledad que el artista confiesa angustiosas en el proceso creativo; el buceo místico de su exquisita sensibilidad en pos de la traza incierta de una visión de lo Absoluto como luz y como forma cromática (G. Gassiot-Talbot, 1968, p. 78; F. A. Albert, 1968 , p. 62). Este pintor cuenta consigo mismo como árbitro y receptor contemporáneo de sus mensajes interpretativos de la experiencia visual como vivencia íntima. La impactante hermosura de sus obras es un privilegio sólo mediato y secundario de sus lectores, una secuela perceptible y participada del conjunto de descubrimientos y de emociones previamente suscitadas y vividas en la atormentada búsqueda del autor. 


\section{ANTONIO GARCIAA BERRIO}

4.2. Soy consciente de que la crítica del arte $-y$ lamentablemente también la solamente comercial, que existe e incluso abunda actualmente (G. Dorfles, 1969, pp. 12-13) - ha producido el descrédito de los términos en que acabo de aludir a la experiencia creadora de Feito. De ahí, en buena parte, la necesidad de renovación de los lenguajes críticos a la que se acoge incluso mi propia iniciativa lingüística, semiológica o-poética. Sin embargo una cosa es ser sensible a los riesgos de la mitificación del proceso de la creación artística y otra diferente $-y$ de consecuencias no menos nefastas - soslayar el hecho de su singularidad sicológica. El absoluto de la calidad artística -con independencia de la relatividad de "valores» sociales, últimamente mercantiles, que tratan de enmascarar o suplantar la realidad de aquel absoluto — se funda en razones de originalidad, novedad, profundidad y capacidad de respuesta empática de los mensajes artísticos elaborados por exploradores privilegiados de la profundidad del arte como experiencia. La honradez esencial de los grandes artistas, Feito entre ellos, y la validez excepcional, fuera del común alcance de sus obras, son definitivamente la garantía innegable. Determinadas dinámicas intelectuales relativistas alentadas en la sociología y la historia postmodernas, han difundido recientemente la paradoja viva del relativismo dogmático (H. G. Gadamer, 1960). No es menos totalitario adherirse a la expansión universal de la imposición relativista, que resistirse a ella desde la independencia de unas vivencias y análisis de la realidad como la que ha practicado tradicionalmente la estética general, artistica y literaria. Una tradición fundada en absolutos pragmáticos de vigencia comunicativa «universalista», que actualmente implica más riesgos de revulsivo inconformista que la presunta progresividad de la abismación relativista.

4.3. En las trivializaciones de las estéticas de la recepción más radicales e inmatizadas - a favor del lugar común, que nadie sensatamente pretende negar, de la importancia diversificadora que concurre en las instancias individuales de la lectura- se omiten las consideraciones más productivas en el interior del fenómeno comunicativo artístico. Una de ellas es la de la comunidad esencial, indescontable, entre la sicología del creador y la de los receptores. Es cierto que el autor comparte con sus lectores y el pintor con los contempladores de sus obras la herencia de imágenes, de sentimientos y de construcciones en que se fundan los mensajes de la comunicación artística, el significado de las obras. $Y$ lo mismo a la inversa. De ahí que la presunta libertad e independencia de las reacciones receptivas respecto a los mensajes codificados de la instancia autorial no dejen de ser entelequias de una formulación teórica paradójica (S. E. Fish, 1980). Es la experiencia común compartida de códigos transindividuales, conceptuales, éticos y estéticos, lo que acota extraordinariamente la condición pretendidamente errática y libérrima del teórico desencuentro que propugna el mito de las lecturas infinitas y de la creatividad independiente del autor sobre la naturaleza del significado general y estético.

A tal respecto, el efecto estético đe las obras de Luis Feito está fuertemente determinado por las ideas y creencias de su autor al codificar sus mensajes de perfección estética absoluta. Es cierto que la apertura semántica de sus composiciones abstractas libera a los contempladores de las obras de Feito de la univocidad conceptual de referentes icónicofigurativos. Incluso el paisaje esencial que suscitan las pinturas de las épocas anteriores (figura 1), ha ido radicalizando su independencia figurativa, su aformalismo sustancial en las obras de la etapa más reciente (figura 3). Sin embargo, ese espacio independiente y holgado para la atribución lectora de significados cubre un ámbito relativamente menor y secundario dentro de la estructura fundamental estética de la significación. En el tipo de abstracciones de Feito, el mensaje estético se vincula al poder de la pujanza estética 


\section{CUADROS Y POEMAS}

del impacto visual y a sus capacidades sentimentales e imaginarias (C. Arean, 1975). Y en ese aspecto pocos son los movimientos sensibles de los espectadores que no hayan sido calculados y prevenidos antecedentemente por Feito en sus larguisimas etapas de gestación de cada nueva serie y de cada cuadro concreto; y pocas son igualmente las reacciones sentimentales sensatas y objetivamente motivadas de los espectadores que puedan sorprender la previsión antecedente de pintores como Luis Feito.

4.4. La relación pragmática del cuadro con el doble vector de la composición autorial y de la recepción visual de los espectadores se ha alterado efectivamente en el conjunto de la creación artística que denominamos globalmente modernas. Como he dicho antes, la apertura de la monosenia clásica en el informalismo moderno es más espontánea y fácil en la pintura que en la literatura - pienso incluso en las metamorfosis de la novela de Proust o de Joyce, o en la inversión del espacio íntimo de la poesía de Shelley a Ungaretti-, con resultados más radicales y perceptibles, habida cuenta de la más difícil liberación semántica de la palabra que la del color. Sin embargo el planteamiento semánticopragmático de una poética plástica como la de Feito obliga a insistir, una vez más, en la necesidad de introducir matices y diferencias en ese bloque convencional del llamado "arte moderno". Este es doblemente indefinido y ambiguo, primero en su dialéctica global de límites históricos muy desdibujados respecto al llamado arte tradicional del periodo clásico, y en segundo lugar respecto de su propia entidad constitutiva: heteróclita y contrastante.

La evidente vocación de modernidad del arte de Feito, por ejemplo, se afirma a través de rupturas menos marcadas seguramente con las reglas estéticas ornamentales constitutivas del arte tradicional: colorido, materiales, sentido de la composición, instrumentación sensible de las formas, etc., que con los presupuestos constitutivos de las estéticas antiornamentales: «minimal", "povera», etc. El concepto de esteticidad u ornamentalidad, como ideal de modulación convencional plástica de la belleza, desprovisto por supuesto de sus adherencias polémicas menos prestigiosas, permite diferenciar en estos días, a mi juicio, una oposición estética no menos radical en el seno de las artes figurativas que la que contrapone el arte abstracto en su conjunto al figurativo. Así por ejemplo, un artista como Feito se identifica escasamente con modernos figurativos como Luis Gordilio o Miguel Barceló, y aún menos con los abstractos y conceptuales todavía más desgarradamente antiornamentales. Mientras que se aproxima con su ideal estético a los eternos maestros de la composición visual y plástica como Piero della Francesca, o con la modernidad exquisita de Braque o de Juan Gris. Armonia que es un principio esencial de la vocación y del entendimiento artístico de la pintura, que aproxima por tanto a pintores remotos entre sí y que desvincula por contrapartida a tantos pintores inmediatos en el espacio y en el tiempo. Por ejemplo a mi juicio, dentro de la actual escala de la refiguración alemana, el expresionismo descoyuntado de $\mathbf{G}$. Baselitz o de $\mathbf{K}$. H. Hödicke difiere radicalmente de las armonías expresionistas de Markus Luppertz, o de los montajes abstractos de G. Richter (T. Krens, M. Govan, J. Thompson, eds., [989).

Esta condición pragmática tradicional de la ornamentalidad o de la esteticidad esencial en la pintura de Feito, una constante espiritual de toda su obra y de su personalidad artística, se ha radicalizado dialécticamente incluso en su rechazo contra la implantación de una cierta conciencia de "renovación salvaje» en el arte moderno a partir de la irrupción triunfante del "pop art» y del cambio hacia América del centro de gravedad del mercado europeo del arte. Las series de Feito en el último decenio, producidas desafiantemente en 


\section{ANTONIO GARCIAA BERRIO}

Nueva York, profundizan una estética depurada en saberes de tradición, de una pintura total, lírica y pura (ver figura 3), donde colores y formas se sutilizan en una retórica variedad del módulo esencial clásico de la belleza ornamental.

4.5. Desde un punto de vista pragmático, por tanto, la modernidad evidente en la vocación artística de Feito se define por una concepción global y unitaria más que meramente continuista del arte como experiencia y participación en la hermosura absoluta, eterna e inmutable. Adherido desde el comienzo sin titubeos ni concesiones, en todo momento, al principio de la ruptura simbólica de la abstracción moderna, Feito ha sabido valorar exactamente los alcances de tradición y diferencia que esa opción inicial implica (M. AlbertLevin, 1968, p. 10). A juicio de Feito, que yo mismo comparto, la destitución figurativa del arte moderno puede ser un paso adelante, obligado incluso desde muchas perspectivas para la evolución de la pintura en la edad de los progresos técnicos; pero esa ganancia polisémica de la pintura no asume en el caso de este pintor ningún otro radicalismo detonante. La libertad del aformalismo no le lleva, como hemos visto antes, ni siquiera a profundizar la tentación, atractiva para otros, de la abdicación autorial en la dirección y la propiedad estética última del significado, frente a las presuntas libertades arbitrarias del lector. Así, las composiciones plásticas de Feito no son más o menos «abiertas» que las construcciones visuales de los grandes maestros clásicos; y son sin embargo mucho más intencionalmente cerradas y directivas de la lectura que el arte programáticamente abierto y dinámico de un Calder o de un Sempere entre los cultivadores del cinetismo, o de Vassarely o Barbadillo en España, entre quienes aceptan la fórmula del arte modular. En linea aún más radical, la obra de Feito es clásica, «antiactual» incluso, si se trata de la gran ruptura con los ideales de pulcritud ornamental del atte de un Anselm Kiefer o entre los españoles de un Miguel Barceló (F. Calvo Serraller, 1987; 1988).

5.1. Buen número de las afirmaciones sobre calidad estética y juicios de valor que hemos hecho en este análisis en relación a la pintura de Feito, no tienen justificación si se mantienen en un entendimiento estrictamente material, compositivo e inmanente del cuadro. Otro tanto hay que decir del texto literario y poético. Entendido así el cuadro o el poema, podemos señalar razones puramente "composicionales» en términos de Bajtín (1978, pp. 35-42), y nunca las causas más inmediatas y operantes de las sanciones estéticas y artísticas sobre mérito y fracaso, logro comunicativo o frustración pragmática. La analítica tradicional lingüística o semiológica de cuadros y de poemas, al fijarse el límite del esquema material del texto y, por tanto, de sus niveles constitutivos como constructos teórico-analíticos, lo que proporcionaba era más bien una descripción de los fundamentos pretendidamente objetivos del juicio estético; pero no aclaraba las razones de necesidad, es decir, la explicación convincente del valor poético.

El camino para lograr este último objetivo de la crítica, hoy más que nunca imprescindible, es extensionalizar el análisis del comportamiento semántico-pragmático de los constituyentes textuales expresivos, intensionalizados éticamente en el cuerpo textual de la obra de arte, cuadro o poema (A. García Berrio, 1991, pp. 29-32). Tradicionalmente ese itinerario de proyección extensional estética de los constituyentes inmanentes del esquema material del texto se producía sobre dos espacios distintos: el socio-histórico y el íntimo sicológico. En la primera tarea se han de distinguir sobre todo los esfuerzos metodológico-críticos del pensamiento marxista, ya sea el más toscamente semántico: Plejánov, Della Volpe, Lukàcs; o el más refinadamente sensible a las valencias autónomas del sistema literario: Adorno, Goldmann, Bajtín (A. García-Berrio, 1973). Los mecanismos 


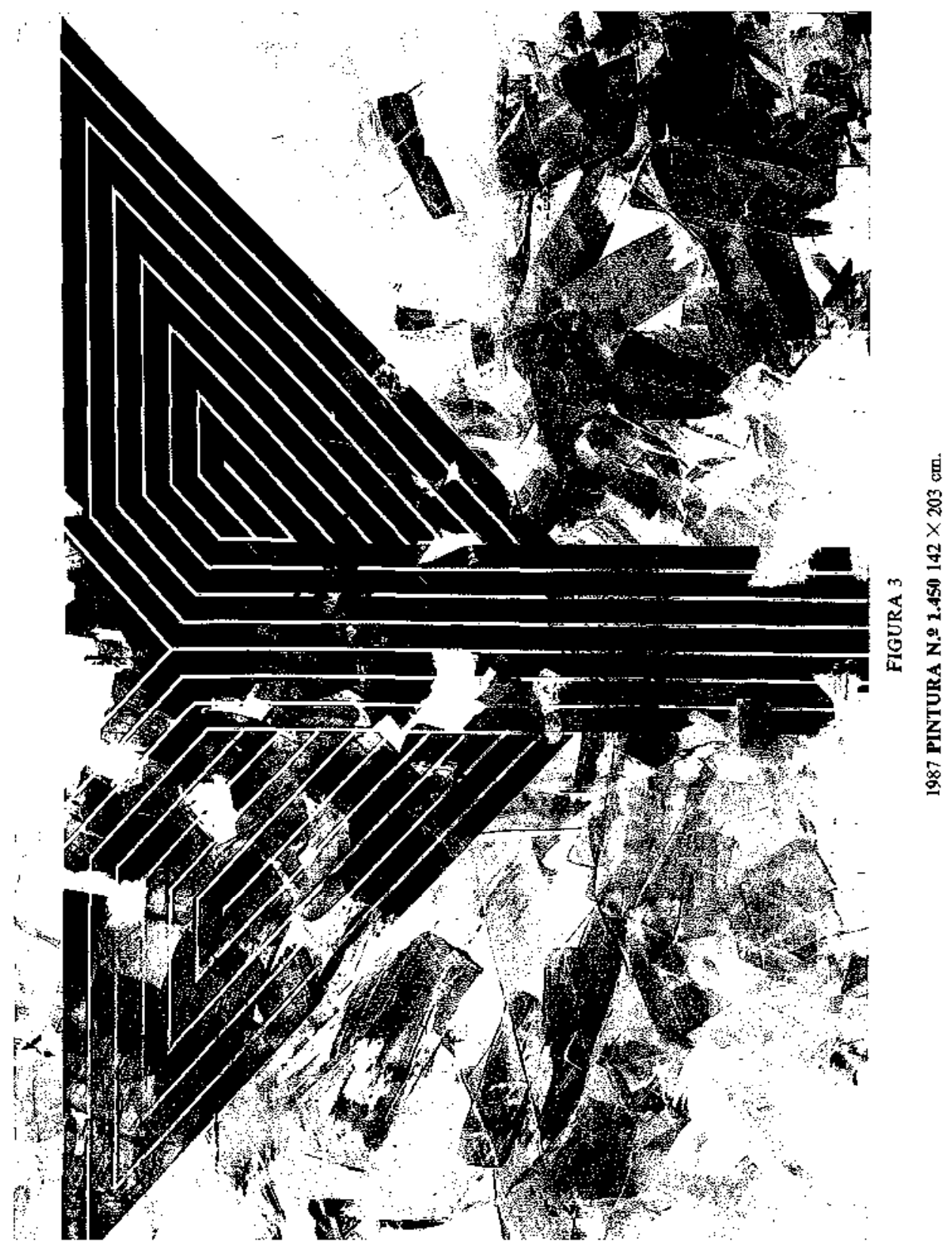





\section{CUADROS Y POEMAS}

de valor del texto literario, y especialmente de determinadas obras como El Paraíso perdido o Guerra y paz, encuentran su explicación en la forma en que instrumentan una orientación universal del sujeto en el mundo de las referencias contextuales externas: históricas, sociales, religiosas, ideológicas, etc... El asunto, en general, es bien conocido; sin embargo me parece que no se ha insistido de forma adecuada aún en presentar la interpretación conceptual, histórica y social como un proceso de extensionalización solidario y continuo del conjunto de indicios estéticos intensionalizados en el texto artístico (F. Jameson, 1971; 1972; 1989).

5.2. Tampoco es nueva la segunda de las vías para producir la comunicación extensionalizada: íntima y sicológica. La psicocrítica y sobre todo el sicoanálisis crítico son ramas bien cimentadas de la crítica literaria (A. Clancier, 1970), que también han dado buenos frutos en el estudio de las obras de arte visual (E. Kris, 1952). Sin embargo en este caso, todavia más radicalmente incluso que en el de la sociocrítica más depurada, puede decirse que hasta ahora se ha desconocido programáticamente la via para conectar la explicación extensionalizante sicológica con el valor expresivo estético de los componentes intensionalizados del texto. Sobre todo, esto es claro en la corriente freudiana del sicoanálisis de autor, la primera en el tiempo y hasta ahora la mejor difundida (J. Spector, 1969). Actualmente conviene poner énfasis sin embargo en la necesidad y en la naturalidad de ambos procesos de extensión, social y sicológica — simultánea, alternada y opcionalmente, según la índole específica de los textos cuestionados - del análisis poetológico o semiótico textual, Porque el concepto inicial «aprisionado» del texto, estructuralista y lingǘsticomaterial, con el que poetólogos y lingüistas procedieron hace quince años, precisa articularse hoy ya realistamente en sus complejas extensiones contextuales sociales y sobre todo en las más inéditas profundidades de su espesor sicológico, antropológico-imaginario (F. Jameson 1972; G. Durand, 1979, pp. 8-45).

A esta propuesta metodológica de extensionalización de la descripción textual clásica para alcanzar un nivel convincente de explicación y aclatación estética de los valores artísticos, vengo contribuyendo en el campo de la literatura desde hace más de diez años. A la vertiente sociológico-histórica se dirigen sobre todo mis trabajos de tipología textual, en la línea de extensionalización social de las peculiaridades formales del texto y del sistema literario, enmarcados conceptualmente en la metodología gramatical de J. S. Petöfi (1973, 1975,1979 ) y en la orientación de la historia de los sistemas de formas de Goldmann y Bajtín (A. García-Berrio, 1979, 1980, 1980a, 1981, 1984, 1985a, 1989, pp. 306-318). En la línea de profundizar en el espesor antropológico-imaginario de los símbolos poéticos del texto artístico, se orienta mi adhesión a la corriente crítica francesa de Poética de lo imaginario inspirada por Gilbert Durand (G. Durand, 1964; A. García-Berrio, 1985). Ambas iniciativas encuentran su encaje en una teoría general del texto literario en la edición española de mi Teoría de la Literatura (A. García-Berrio, 1989, pp. 370-437). A su vez, el proceso en el análisis de los textos de arte visual correspondiente a la propuesta textual imaginaria para la literatura, lo he bosquejado también en trabajos individuales (1984a) y en colaboración con M. T. Hernández (1987) y sobre todo extensamente en el libro Ut poesis pictura: Poética del arte visual, (1988, pp. 98-106 y pp. 199 y ss.).

La indicación de estas dos maneras diferentes, si no contrapuestas, de extensionalizar el análisis trađicional poetológico de los textos no nace de una imposición estratégica interna del sistema metodológico; muy al contrario, viene dictada por dos entendimientos tradicionales muy distintos de la función de la literatura y del arte. En obras como La Eneida - la Comedia homana de Balzac predomina la intención épica exorreferencial, histórica y 


\section{ANTONIO GARCIA BERRIO}

social, que las hace particularmente idóneas a la extensionalidad histórica de las aclataciones críticas. Por el contrario en los poemas amorosos de Safo, en los de La vida mieva del Dante o en la mayoría de los idilios de Leopardi, la preponderancia textual de una línea experiencial de endorreferencialidad íntima, lírica, hace seguramente más necesaria y pertinente para el juicio último de su valor estético la elucidación de los simbolos y movimientos sicológicos. Estos se evidencian con las marcas de expresividad material del texto y se produndizan en una construcción de la experiencia artística como plasmación y comunicación del universo íntimo del autor, tejido en la red de símbolos y de rumbos espaciales de su orientación antropológico-imaginaria (A. Garcia-Berrio, 1987, pp. 181-188).

\subsection{Pocas duđas caben a propósito de la pintura de Feito sobre la superior condición} ilustrativo-causal de la línea de extensionalización sicológica entre los dos itinerarios que acabo de indicar. Y no es que las referencias políticas e históricas en que se enmarca la biografía de Feito carezcan de importancia en la caracterización de su obra: su adhesión estética e ideológica a un grupo «progresista» y artísticamente revulsivo como El Paso en el Madrid de los cincuenta; la distancia de exiliado con la que discurre la existencia francesa de Feito durante el periodo de la dictadura española; su actual residencia polémica y militante en Nueva York, etc., etc. (C. Arean, 1975: F. Huici, 1988; A. Garcia-Berrio y M. T. Hernández, 1988, pp. 84-89). Sin embargo predomina sobre todo la pureza plástica de la obra de Feito, el proceso continuado en su poética de creciente desentendimiento y borrado de cualquier marca de referencialidad exterior, la emoción absoluta de sus cuadros como éxtasis absolutos en los que se intuyen trasuntos depurados de hondas vivencias espirituales en la dulzura última del místico. Naturalmente detrás de tantas delicias se encuentran los momentos de dolorida ascesis de la búsqueda, gestos de tensión sin embargo elegantemente disimulados en sus pinturas; todo lo cual ofrece la contemplación de estos cuadros como el ejercicio esencial de comunicación íntima de un alma interesante.

Puede añadirse, incluso, que tal vez el proyecto general de la obra de Feito se corresponde con una dirección genérica del arte europeo moderno. La conversión de la referencialidad épica del arte clásico hacia el paisaje íntimo de los afectos y de la imagen espiritual interior fue ya identificada globalmente por el propio Hegel como caracteristica fundacional del arte postclásico europeo y, según él, romántico. El proceso se aclara, además, desde el Romanticismo a las vanguardias bajo el signo, en mi opinión más concluyente, de la destitución de las coordenadas convencionalmente objetivas de la referencialidad exterior, postural y diurna, por el buceo en el espacio de dimensiones siempre inciertas de la introspección del subjetivismo nocturno. Incluso la modalidad genérica moderna más subjetiva y épica, la novela, conoce en sus mayores cumbres desde Proust, Joyce y Kafka el deterioro del juego externo de referencias, ahondado con mayor naturalidad por la lírica desde las cosmogonías alternativas de Blake o de Lautréamont a la escritura poética moderna de perfiles oníricos más quebrados como la de García Lorca o Vicente Aleixandre (F. Calvo Serralier, 1989).

La pintura abstracta en general, y la de Feito en concreto por excelencia, ha consumado con ejemplar radicalismo el proceso de introspección de una referencialidad con las dimensiones del referente destituidas por propia naturaleza. El protagonisno del espacio, con el de la luz y el del cromatismo en la pintura abstracta de Feito, se refiere en exclusiva al del espacio exento y autónomo del cuadro: un microcosmos espacial, un acotamiento convencional asumido, donde los movimientos de orientación de la expresión y la lectura sensitiva se constituyen en esquema imaginativo metafórico, traslaticio, de un universo de dimensiones espirituales perfectas. El valor estético de la pintura de Feito 
viene garantizado por la variedad, la riqueza y la convicción esencial de una austera instrumentación de los significantes más puros, puestos al servicio de la comunicación de una exploración interior en las canteras luminosas de la belleza esencial. Un sentimiento que prueba la legítima autenticidad de sus raíces, a mi juicio, en la medida en que radicaliza su fórmula magistral sin alterarse, más allá de las modificaciones ocasionales que lo animan y diversifican de modo permanente. La grandeza de las obras de Feito, su valor de comunicación esencial de bellezas, las raíces últimas de su necesidad radican, como las de todo arte sublime, en ese místerioso espesor envolvente que emana del soporte material del cuadro y que sabe englobar y asumir el trabajo imaginario y las delicias de la fantasia sensitiva de los espectadores.

5.4. La fascinación simbólica fundamental de Feito se reconoce en su tarea de rescate de la experiencia nocturna para el esplendor del día (A. García-Berrio, 1985, 1987, 1989, pp. 370-404). La profundidad que respetamos en sus obras radica exactamente en la hondura, ajena a la experiencia cotidiana y común, de la raíz de sus símbolos morfológicos, en la remota procedencia radical de sus fótmulas de color y de Juminosidad. El fundamento perceptible de la emoción de estos cuadros y de su valor estético consiste en último término en una emoción de raíces antropológico-imaginarias. Las pinturas de Feito - las de cualquier periodo- están impregnadas de una fascinación transcendental; son mensajes de una profundidad del ser en su cuestionamiento sobre las razones de causa absoluta que se alojan en las tinieblas gozosas del abismo intimo. Tantean ef misterio, comunicándolo bajo el gozo de sus mensajes plásticos radiantes, inundados de luz y transidos de eternidad y de equilibrio. No se reconoce el poder erótico de la creación de Feito en la dinamicidad báquica y expresiva incesante de Picasso; antes bien reside en su fuerza creadora, poderosa y serena; se mide en las profundidades del rescate y en el control, dulcísimo pero tenaz, de su plasmación del texto.

Esta formulación diurna y radiante de los símbolos de la experiencia casi mística en el espacio incierto del más allá se consigue a través del ideal de depuración. Desde el punto de vista de la semántica simbólica, Feito ha ido transformando las piezas referenciales de su paisaje exterior de la primera época, solar y curvo, en la geometría abstracta y angulosa de sus coordenadas rectilíneas, donde se sustenta la lluvia de flores que inunda las obras del último decenio. Es decir, ha profundizado la fórmula de una sintaxis espacial de la orientación imaginaria en el espacio (A. García-Berrio, M. T. Hernández, 1988, pp. 187-199), que impone su nitidez esencial sobre cualquier tentación de frondosidad semántica de los símbolos. Igual que se reconoce a los poetas puros - Valéry, Guillén - frente a los de densidad simbólica -Baudelaire, García Lorca-por el predominio de la linealidad sintáctica de sus esquemas poéticos y por la economia esencial de su semántica simbólica, los pintores como Feito o Klee se caracterizan por la pureza esquemática de su sintaxis, frente a la densidad simbólica de la semántica de otros como De Kooning o Pollock. Intepretar expresivamente en el cuadro, en el esquema material del texto plástico, la profundidad emotiva del espesor fantástico de la imaginación, es en todos los casos y estilos la clave y la gradatoria del valor poético (A. Gatcía-Berrio, 1989, pp. 471-480).

La instrumentación artística del arte moderno como la que lleva a cabo Luis Feito, rescatando a formas bellísimas de atractivo luminoso las inágenes puras de su exploración interior de la Belleza total, hunde por tanto sus raices en los fundamentos menos convencionales del arte moderno; aquellos donde los límites esenciales de la tradición y el aformalismo se confunden y desvanecen en la gloria común de la experiencia del arte visual como delicia absoluta. El valor anticonvencional de este tópico de la pintura moderna 
contradice por tanto el tan generalizado prejuicio actual sobre la supuesta convencionalidad del valor artístico, según la cual la grandeza estética de la obra de arte será siempre ajena a valores subjetivos y universalizables.

No es cometido de este estudio, siendo su finalidad general la discusión metodológica y su objeto concreto la reflexión sobre el arte de Feito, atender también a los debates, tan interesados como triviales, sobre el convencionalismo radical -es decir estéticamente arbitrario- del arte moderno deconstruido en sus razones objetivas y universales de necesídad estética. El auge casi recién transcurrido ya de la refiguración postmoderna, expresionista o manierista, o el vigente ahora de un nuevo conceptualismo (C. Gintz, ed., 1989), alternando o sucediendo a la casi infinita retórica de los varios episodios antidecorativos del arte moderno -duren unos y otros lo que duraren-, no puede desarraigar la legitimidad moderna de la pintura de Feito; ni mucho menos de construir la "consistencia» (A. García Berrio, 1991) de los fundamentos universales de legitimidad estética, a los que se adhiere la inalterable vocación de belleza de su designio artístico.

\section{Bibliograf́a}

Albert-Levin, Marc (1968), Feito, painter, en V. A., pp. 1-5.

Alonso, Amado (1961), Estudios lingüisticos: Temas españoles, Madrid, Gredos.

Alport, F. (1955), Theories of Perception and the Concept of Structure, Nueva York, Willey.

Arean, Carlos (1975), Feito, Madrid, Ministerio de Educación y Ciencia (Artistas Españoles Contemporáneos).

Ambrogio, Ignazio (1968), Fomalismo e avanguardia in Russia. Roma, Riuniti.

Arnheim, Rudolph (1954), Ant and Visual Perception, Berkeley, University of California Press.

Bajtín, Mijail (1978), Esthétique et théorie du Roman, Paris, Gallimard.

Battisti, E. (1974), "The Role of Semiology in the Study of Visual Art», in S. Chatman, (ed.).

Boudaille, Georges (1968), A la découverte de Luis Feito, en V. A., p. 20.

Calabrese, Omar (ed.) (1980), Semiotica della pittura, Milán, Il Saggiatore.

-_(1985), El lenguaje del arte, Barcelona, Paidós.

Calvo Serraller, F. (1986), Luis Gordillo, Madrid, De León.

- (1987), Imágenes de lo insignificante, Madrid, Taurus.

_-(1987a), "Les colonnes d'Hercule et la fin du monde», en Cinq Siecles d'Ari Espagnol, Paris.

- (1988), Del futuro al pasado. Vanguardia y tradición en el arte español contemporáneo, Madrid, Alianza Forma.

- (1989), La novela del artista, Madrid, Mondadori.

Chatman, Seymur (ed.) (1974), A Landscape of Semiotics, La Haya, Mouton.

Clancier, Anne (1970), Psychanalyse et Critique littéraire, Toulousse, Privat.

Crispolti, E. (1968), Ricerche dopo l'Informale, Roma, Officina,

Culler, Jonathan (1975), Structuralistic Poetics: Structuralism, Linguistics and the Study of Literature, Ithaca, Cornell University Press.

-(1982), On Deconstruction, Ithaca, Cornell University Press.

Curter, C. L. (1976), «Painting and Language: A Pictorial Syntax of Shapes», in Leonardo, 9.

Damisch, H. (1972), Théorie de limage, París, Seuil. 


\section{CUADROS Y POEMAS}

—- (1974), "Huit thèses pour (ou contre?) la Sémiologie de la peinture», en S. Chatman (ed,).

-_(1984), Fenêtre jaune cadmium, París, Seuil.

Dorfles, Gilo (1969), Uiltinas tendencias del arte actual, Barcelona, Labor.

Durand, Gilbert (1964), Les Estructures Anthropologiques de l'Immaginaire, París, P.U.F.

- (1979), Figures Mitiques et Visages de l'Oeuvre, París, Berg.

Eco, Umberto (1979), The Role of the Reader, Londres, Utchinson.

(1990), I limiti dell' interpretazione, Milán, Bompiani.

Ellis, J. (1974), The Theory of Literary Criticism. A Logical Annalysis, Berkeley, University of California Press.

Fish, Stanley E. (1980), Is There a Text in This Class?, Cambridge Mass., Harvard University Press.

Floch, J. M. (1981), "Sémiotique d'un discours plastique non figuratif", en Commumication, $34, \mathrm{pp}, 135+158$.

Fuchs, Rudi (1990), Baselitz painting en V. A., Georg Baselitz, Barcelona-Madrid, Fundación Caja de Pensiones.

Gadamer, Hans Georg (1960), Truth and Method, Nueva York, Seabury Press, 1975.

García-Berrio, Antonio (1973), Significado actual del Formalismo ruso, Barcelona, Planeta.

- (1979), Semiótica textual de un discurso plástico: E. Brinkmann, Montpellier, Université Paul Valéry (col. Etudes Sociocritiques).

- - (1979a), «A Text-Typology of the Classical Sonnets», en Poética, 8, pp. 435-458.

- (1980), "Una tipologia testuale di sonetti amorosi nella tradizione classica spagnola», en Lingua e Stile, III, pp. 451-478.

(1980a), "Text-linguistics and the Lyric Text», en E. Forastieri (ed.), On text and Context. Methodological Approaches to Context of Literature, Puerto Rico, University of Río Piedras.

- (1981), "Macrocomponente textual y sistematismo tipológico: el soneto amoroso español de los siglos XVI y XVII y las reglas del géneron, en Zeitschrift für Romanische Philologie, 97, 1-2, pp. 146-171.

(1984), «Topical Tradition and Textual Complexity», en Poetics Today, 4, pp. 707721.

-(1984a), “Antonio Saura: espacio imaginario y tiempo del hombre», en Revista de Occidente, 32, pp. 127-146.

(1985), La construcción inaginaria en "Cánticon de Jorge Guillén, Limoges, Université, TRAMES.

(1985a), «Sociocrítica y formalismo a la luz de las tipologías textuales», en Homenaje a J. A. Maravall, Madrid, CSIC, II, pp. I17-128.

-.-(1987), "¿Qué es lo que la poesía es?», en Lingülstica Española Actual, IX, 2, pp. $177-188$.

- (1989), Teorla de la literatura. La construcción del significado poético, Madrid, Cátedra.

(1989a), «La lecture lyrique», en Versus, 52-53, pp. 71-80.

- (1991), "Gustavo Torner, en la consistencia expresiva del arte moderno", en Torner, Madrid, Centro de Arte Reina Sofía, pp. 25-44.

- - y Hernández, M. T. (1987), "The semiotics of discourse and of the plastic text: on the textual scheme and imaginary construction", en Dispositio, X, 27, pp. 127-160. -(1988), Ut poesis pictura. Poética del arte visual, Madrid, Tecnos.

Garroni, Emilio (1964), La Crisi Semantica delle Arti, Roma, Officina.

-_(1973), Immagine e Linguaggio, Urbino, CISL. 


\section{ANTONIO GARCIA BERRIO}

Gassiot-Talbot, Gerald (1968), Les peintres célebres, en V. A., p. 78.

Gella, T. (1978), «The intrinsic dynamic of the Syntax in the visual sign» en Semiotica, 3-4.

Ginz, Claude (ed.) (1989), Conceprual Art. A Perspective, París, Musée d'Art Moderne de la Ville de Paris.

Gombrich, E. H. (1959), Art and Illusion, Nueva York, Pantheon Books.

--(1966), Norm and Form. Studies in the Art of the Remaissance, Londres, Phaidon.

Graham, C. E. (ed.) (1965), Vision and Visual Perception, Nueva York, Wiley.

Grahmann, W. (1966), Kunst umserer Zeit, Colonia, Schausberg.

Group « $\mu$ (1979), Trois fragmenis pour ume Rhétorique de l'mage, Urbino, CISL.

Harweg, Roland (1968), Pronomina und Text-Konstitution, Munich, Fink.

Hernández Guerrero, J. A. (1990), "A modo de prólogon, en Teorfa del Arte y Teoría de la Literatura, Cádiz, Universidad, pp. 9-36.

Holub, R. C. (1984), Reception Theory: A Critical Introduction, Nueva York, Methuen.

Huici, Fernando (1988), Feito, Madrid, Museo Español de Arte Contemporáneo.

Iser, Wolfgang (1976), The Act of Reading, Baltimore, Jobn Hopkins University Press, 1978 .

Jameson, Frederic (1971), Marxism and Form, Princeton, Princeton University Press.

- -(1972), The Prison-House of Language, Princeton, Princeton University Press.

(1989), Documentos de cultura, documentos de barbarie, Madrid, Comunicación.

Joffé, H. L. (1966), «Syntactic Structures in Visual Art», in G. Kepes (ed.), Structure in Art and Science, Nueva York, Brazimer.

Kjourp, S. (1980), "Languages de l'image et đ’autres langages», in Degrés, 2, 1.

Krens, Thomas - Govan, Michael - Thomson, Joseph (eds.) (1989), Refigured Painting.

The Geman Image 1960-1988, Nueva York, S. R. Guggenheim Museum.

Kris, E. (1952), Psychoanalytic Explorations in Art, Nueva York, Schocken Books.

Lagrange, M. S. (1973), Analyse Sémiotique et Histoire de l'Art, Paris, Klincksieck.

Langer, S. K. (1953), Feeling and Form, Nueva York, Scribner's.

(I957), Problems of Art, Nueva York, Scribner's.

Lindekens, R. (1976), Essai de Sémiotique Visuelle, París, Klincsieck.

Lotman, Jurij - Gasparov, B. (1979), "La Rhétorique du non verbal», en Révte d'Esthetique, $\mathrm{I}-2$.

Man, Paul de (1981), Blindness and Insight: Essays in the Rhetoric of Contemporary Criticism, Londres-Nueva York, Oxford University Press.

Marin, Louis (1970), «La description de l'image», en Communications, 15, pp. 186-206. (1975), À propos d'un carton de Le Brun: le lableau d'histone et la dénégation de l'énonciation, Urbino, CISL.

(1978), Estudios semiológicos (La lectura de la imagen), Madrid, Comunicación. (1981), "Pyrame et Tysbé», en Versus, 29.

Mathey, François (1968), Luis Feito, en V. A., p. 40.

Mathieu, Georges (1959), «D'Aristote à l'Abstraction Lyrique», en L'Oeil, 52.

Mattescu, Catalina Anca (1974), "Toward a Structural Approach to Pictural Language», en Poetics, 1 , pp. 44-61.

Nanni, L. (1980), Per uma nuova Semiologia dell'Arte, Milán, Garzanti.

Passeron, René (1962), L'oetwre d’àt et les fonctions de l'apparence, París, Plon.

- (1980), "Sull'apporto della poetica alla semiologia del pittorico", en O. Calabrese (ed.), pp. 33-48.

Petöfi, Janos, S. (1973), «Towards an Empirically Motivated Grammatical Theory of Verbal texts», en Petöfi, J. S. - Rieser, H. (eds.), Studies in Text Grammar, Dordrecht, Reidel, pp. 207-275. 


\section{CUADROS Y POEMAS}

- -(1975), Vers une théorie partielle du texte, Hamburgo, Buske.

--y García Berrio, Antonio (1979), Lingüística del Texto y Crifica Liferaria, Madrid, Comunicación.

Raffa, Piero (1976), Semiologia delle Arte Visive, Bolonia, Patron.

Rieser, H. (1957), "The Semantic Theory of Art in America", en The Joumal of Aesthetic and Art Criticism, 3.

Restany, Pierre (1968), Le lyrisme castillian, en V. A., pp. 26-28.

Schefer, R. L. (1970), Escenografía de wn cuadro, Barcelona, Seix Barral, 1990.

- -(1971), "Lecture et système du tableau», en J. Kristeva (ed.), Essay's in Semiotics, La Haya, Mouton.

--(1977), La peste, le déluge, Paolo Ucello, París, Galilée.

(1980), La lumiere et la proie. Anatomies d'une figure religieuse: Le Corrège, París, Albatros.

Sobejano, Gonzalo (1970), El epiteto en la lirica española, Madrid, Gredos.

Spector, J. (1969), «Les méthodes de la critique d'art et de la psychanalyse Freudien», en Diogène, 66.

Tieghem, Paul van (1921), «La synthèse en histoire littéraire», en Révtue de syntèse historique, XXVI, pp. $1-27$.

Uspenskij, Boris A. (1969), "Sulla Semiotica dell'arte», en R. Faccani - Eco, U. (eds.), I sistemi di Segni e lo Strutturalismo Sovietico, Milán, Bompiani.

--(1976), The Semiotics of the Russian Icons, Lisse, Riddler.

V. A. (1968), Luis Feito, París, S. M. I.

Vattimo, Giovanni - Rovatti, Pier Aldo, eds. (1983), Il pensiero devole, Milán, Feltrinelli. 